We conclude that aortic valvuloplasty with an isolated triangular resection of the prolapsing cusp is an easy and effective technique for the treatment of the aortic insufficiency in children with VSD.

\section{REFERENCES}

1. Keane JF, Plauth WH, Nadas AS. Ventricular septal defect with aortic insufficiency. Circulation 1979;56(Suppl):172-7.

2. Cosgrove DM, Rosenkranz ER, Hendren WG, Bartlett JC, Stewart WJ. Valvuloplasty for aortic insufficiency. J Thorac Cardiovasc Surg 1991;102:571-6.

3. Chauvaud S, Serraf A, Mihaileanu S, Soyer R, Blondeau P, Dubost $C$, et al. Ventricular septal defect associated with aortic valve incompetence: results of two surgical managements. Ann Thorac Surg 1990;49:875-80.
4. Cosgrove DM, Fraser CD. Aortic valve repair. In: Cox JL, Sundt TM, editors. Operative techniques in cardiac \& thoracic surgery: a comparative atlas. Philadelphia: WB Saunders; 1996. p. 30-7.

5. Schoof PH, Cromme-Dijkhuis AH, Bogers JJ, Thijssen EJ, Witsnburg M, Hess J, et al. Aortic root replacement with pulmonary autograft in children. J Thorac Cardiovasc Surg 1994;107:367-73.

6. Elkins RC, Knott-Craig CJ, Ward KE, McCue C, Lane MM. Pulmonary autograft in children: realized growth potential. Ann Thorac Surg 1994;57:1387-93.

7. van Son JAM, Reddy VM, Black MD, Rajasinghe H, Haas GS, Hanley FL. Morphologic determinants favoring surgical aortic valvuloplasty versus pulmonary autograft aortic valve replacement in children. J Thorac Cardiovasc Surg 1996;111: $1149-57$.

\title{
RUPTURED MEDIASTINAL BRONCHIAL ARTERY ANEURYSM: A DILEMMA OF DIAGNOSIS AND THERAPEUTIC APPROACH
}

\author{
Afksendiyos Kalangos, MD, PhD, Gregory Khatchatourian, MD, Aristotelis Panos, MD, and Bernard Faidutti, MD, \\ Geneva, Switzerland
}

Bronchial artery aneurysm is a rare entity that is observed in fewer than $1 \%$ of all cases of selective bronchial arteriography. ${ }^{1}$ It can be classified as mediastinal, intrapulmonary, or both. The mediastinal localization may manifest various symptoms simulating clinical pictures of aortic dissection or rupture of an aortic aneurysm that could raise some challenging problems. ${ }^{2,3}$ We report a case complicated by life-threatening massive bleeding from a ruptured mediastinal bronchial artery aneurysm mimicking a clinical picture of aortic dissection. The mechanisms of formation, clinical presentation, and therapeutic management of mediastinal bronchial artery aneurysms are discussed with reference to the 13 previously reported cases in the literature (Table I). ${ }^{1-11}$

Clinical summary. A 50-year-old man was brought to a local hospital because of the sudden onset of severe back pain radiating to the abdomen during a mountain excursion. Blood pressure was $95 / 60 \mathrm{~mm} \mathrm{Hg}$, pulse rate 110 beats/min, and respiratory rate 18 breaths/min. The breath sounds were decreased over the left hemithorax. The chest $\mathrm{x}$-ray film revealed a left hemothorax with no

From the Clinic for Cardiovascular Surgery, University Cantonal Hospital of Geneva, Geneva, Switzerland.

Received for publication Feb. 3, 1997; accepted for publication March 17, 1997.

Address for reprints: Afksendiyos Kalangos, MD, PhD, Clinic for Cardiovascular Surgery, University Cantonal Hospital of Geneva, 24, rue Micheli-du-Crest, 1211 Geneva, 14, Switzerland.

J Thorac Cardiovasc Surg 1997;114:853-6

Copyright $(\mathcal{C} 1997$ by Mosby-Year Book, Inc.

$0022-5223 / 97 \$ 5.00+0 \quad \mathbf{1 2 / 5 4 / 8 1 9 4 2}$ evidence of mediastinal widening or suspicious images on the pulmonary parenchyma. Chest computed tomographic (CT) scan confirmed the left hemothorax and excluded aortic dissection. However, a suspicious vascular mass in the midportion of the mediastinum, ventral to the descending aorta, was visualized, but its nature could not be

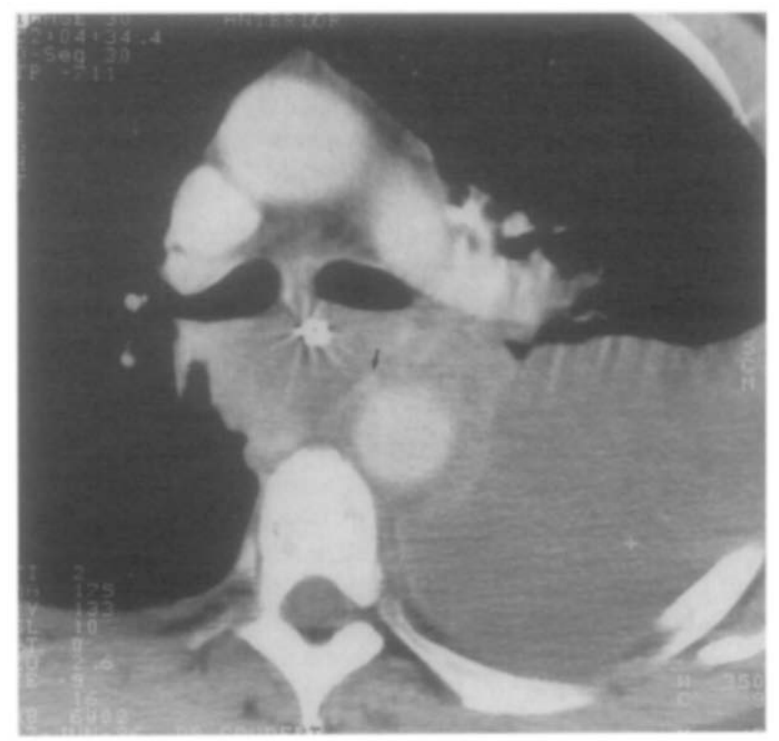

Fig. 1. Chest CT scan showing an abnormal vascular structure ventral to the descending aorta (arrow). Note the presence of the large left hemothorax and the absence of dissection in the descending aorta. 
Table I. Reported cases of mediastinal bronchial artery aneurysm

\begin{tabular}{|c|c|c|c|c|c|c|c|c|}
\hline $\begin{array}{l}\text { First } \\
\text { author } \\
\text { (year) }\end{array}$ & $\begin{array}{c}\text { Age (yr), } \\
\text { sex }\end{array}$ & Etiology & Localization & Size $(\mathrm{mm})$ & Symptom & $\begin{array}{c}\text { Diagnostic } \\
\text { tool }\end{array}$ & Treatment & Outcome \\
\hline Hirano $^{5}$ & $58, \mathrm{M}$ & NA & Right & $9 \times 8 \times 6$ & None & NA & NA & NA \\
\hline (1976) & $54, \mathrm{~F}$ & NA & Left & $5 \times 5 \times 5$ & None & NA & NA & NA \\
\hline Hall $^{2}(1977)$ & $56, \mathrm{M}$ & Bronchiectasis & Left & 9 & $\begin{array}{l}\text { Aortic } \\
\text { dissection }\end{array}$ & Angiography & $\begin{array}{l}\text { Left lower } \\
\text { lobectomy }\end{array}$ & Uneventful \\
\hline $\begin{array}{l}\text { Chantepie }^{6} \\
(1980)\end{array}$ & $\begin{array}{l}15 \text { days, } \\
\text { F }\end{array}$ & Mycotic & Left & 15 & Hemoptysis & Angiography & $\begin{array}{l}\text { BAA cannot be } \\
\text { resected + left } \\
\text { upper lobectomy }\end{array}$ & Died \\
\hline Watanabe $^{7}$ & $55, \mathrm{M}$ & NA & NA & $9 \times 11$ & None & NA & $\mathrm{NA}$ & NA \\
\hline (1981) & $70, \mathrm{M}$ & NA & Right & $12 \times 11$ & None & NA & NA & NA \\
\hline $\begin{array}{l}\text { Abet }^{3} \\
\quad(1981)\end{array}$ & $50, \mathrm{M}$ & Atherosclerosis & Right & 9 & $\begin{array}{l}\text { Aortic } \\
\text { dissection, } \\
\text { shock }\end{array}$ & Angiography & $\begin{array}{l}\text { Cardiac arrest } \\
\text { during left } \\
\text { thoracotomy }\end{array}$ & Died \\
\hline \multirow[t]{2}{*}{$\begin{array}{l}\text { Osada }^{8} \\
\quad(1986)\end{array}$} & $62, \mathrm{~F}$ & Bronchiectasis & Left & $30 \times 30$ & None & $\begin{array}{l}\text { CT scan, } \\
\text { angiography }\end{array}$ & $\begin{array}{l}\text { Surgical ligation }+ \\
\text { sclerosing agent } \\
\text { into the cavity }\end{array}$ & Uneventful \\
\hline & $56, \mathrm{~F}$ & Not elucidated & Right & $10 \times 12$ & Hemoptysis & Angiography & $\begin{array}{l}\text { After embolization, } \\
\text { surgical extirpation } \\
\text { + right upper } \\
\text { lobectomy }\end{array}$ & Uneventful \\
\hline $\begin{array}{l}\text { Shaer }^{9} \\
\text { (1989) }\end{array}$ & $79, \mathrm{M}$ & Atherosclerosis & Right & 10 & Hematemesis & CT scan & None & Died \\
\hline $\begin{array}{l}\text { Remy- } \\
\text { Jardin } \\
(1991)\end{array}$ & $50, F$ & Bronchiectasis & Left & 10 & Hemoptysis & Angiography & Embolization & $\begin{array}{r}\text { No efficient } \\
\text { occlusion }\end{array}$ \\
\hline $\begin{array}{l}\text { Fujita }^{1} \\
\text { (1991) }\end{array}$ & $66, \mathrm{~F}$ & Atherosclerosis & Right & 25 & None & $\begin{array}{l}\text { CT scan, } \\
\text { angiography }\end{array}$ & $\begin{array}{l}\text { Right lower } \\
\text { lobectomy }\end{array}$ & Uneventful \\
\hline $\begin{array}{l}\text { Cearlock }^{11} \\
\text { (1995) }\end{array}$ & $22, \mathrm{M}$ & Traumatic & Left & $15 \times 10$ & Hemoptyis & Angiography & Embolization & $\begin{array}{l}\text { Efficient } \\
\text { occlusion }\end{array}$ \\
\hline $\begin{array}{r}\text { Ishizaki }^{4} \\
\quad(1995)\end{array}$ & $22, \mathrm{~F}$ & $\begin{array}{l}\text { Osler-Weber- } \\
\text { Rendu }\end{array}$ & Right & 5 & $\begin{array}{l}\text { Aortic } \\
\text { dissection, } \\
\text { shock }\end{array}$ & At thoractomy & $\begin{array}{l}\text { Surgical exploration } \\
+ \text { embolization }\end{array}$ & $\begin{array}{l}\text { Efficient } \\
\text { occlusion }\end{array}$ \\
\hline $\begin{array}{l}\text { Present study } \\
\text { (1997) }\end{array}$ & $50, \mathrm{M}$ & Degenerative? & Left & $15 \times 15$ & $\begin{array}{l}\text { Aortic } \\
\text { dissection, } \\
\text { shock }\end{array}$ & At thoractomy & Surgical ligation & Uneventful \\
\hline
\end{tabular}

$N A$, Not available; $C T$ scan, computed tomographic scan; $B A A$, bronchial artery aneurysm.

identified with certainty (Fig. 1). On referral to our institution, he abruptly went into hypovolemic shock and required massive blood and fluid transfusions. The patient was immediately taken to the operating room. Partial cardiopulmonary bypass was instituted with inflow into the right femoral artery and venous return to the pump from a long cannula placed into the right atrium through the right femoral vein. A perioperative transesophageal echocardiogram excluded the presence of aortic dissection or aortic aneurysm. A bilateral transsternal anterolateral thoracotomy revealed a large blood effusion in the left extrapleural space and $3000 \mathrm{ml}$ of clotted and unclotted blood in the left pleural cavity. A subadventitial hematoma was found along the descending aorta extending toward the aortic arch and the middle mediastinum. The pericardium was opened to determine whether the bleeding had originated in the ascending aorta or the aortic arch, but the appearance and diameter of these two aortic segments were normal. Dissection of the descending aortic adventitia revealed an active bleeding site from a juxtaaortic structure. Further dissection of the middle mediastinum showed that the bleeding was coming from a mediastinal bronchial artery aneurysm, $15 \mathrm{~mm}$ in diameter, with a ventral origin from the descending aorta (Fig. 2). It was ligated proximally and distally and the aneurysmal sac was compressed by large vascular clips after biopsy. The postoperative course was uneventful. Histopathologic examination of the specimen revealed no evidence of atherosclerotic or inflammatory changes but did show signs suggestive of medial degeneration characterized by broken elastic laminae.

Discussion. Bronchial artery aneurysms are reported to occur as isolated or associated mediastinal and intrapulmonary anomalies. They are usually found in cases of bronchiectasis or recurrent bronchopulmonary inflammation. However, in some cases, atherosclerosis, ${ }^{3,9}$ infection, ${ }^{6}$ trauma, ${ }^{11}$ and Rendu-Osler-Weber syndrome ${ }^{4}$ have been demonstrated to predispose bronchial arteries to aneurysmal dilatation. For the few cases in which the cause has not been elucidated in detail, a proposed 


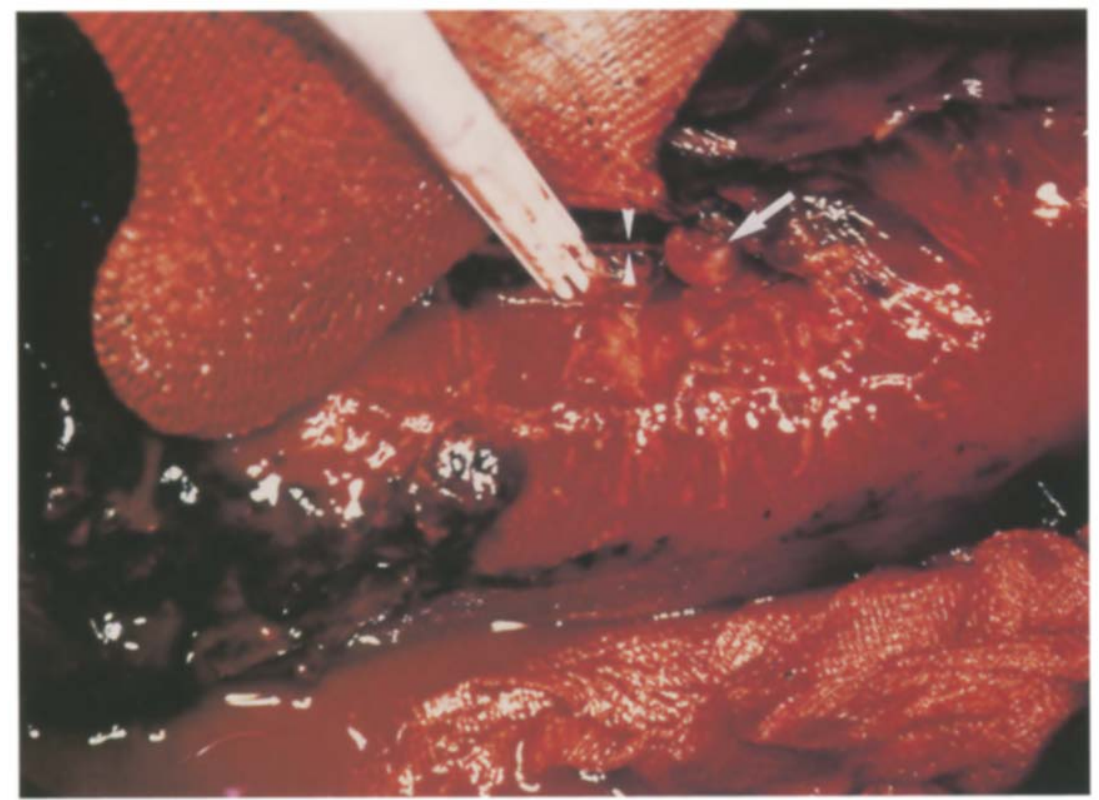

Fig. 2. Operative view of the ruptured bronchial artery aneurysm (arrow) at the ventral proximity of the descending aorta. Note the bleeding jet stream from the bronchial artery aneurysm (between arrowheads) toward the sucker.

hypothesis is that increased bronchial arterial flow to the lungs owing to various factors could be a possible mechanism of bronchial artery dilatation and subsequent aneurysm formation. The formation of our patient's bronchial artery aneurysm raises doubts in favor of medial degenerative changes or the aforementioned hypothesis of increased bronchial artery flow to the lungs, because no associated bronchopulmonary, atherosclerotic, or mycotic origin was demonstrated. Bronchial artery aneurysms can stay asymptomatic until rupture. Although little is known about the process that leads the aneurysm to rupture, the various sizes of ruptured mediastinal bronchial artery aneurysms in reported cases have revealed that diameter is not an incremental risk factor for rupture. Rupture into the pulmonary parenchyma mainly presents as hemoptysis, whereas a rupture into the mediastinum, in the pleural space, ${ }^{2-4}$ bronchus, ${ }^{6,8,10,11}$ or esophagus, ${ }^{9}$ may simulate symptoms of aortic dissection or aortic rupture with subsequent shock. The severe tearing pain in the central portion of the chest radiating into the back and epigastrium is due to blood stripping from the mediastinum, containing the ruptured extraaortic vessel into the subadventitial aortic and extrapleural areas. When adventitial or pleural barriers are broken, the clinical picture is that of a ruptured thoracic aneurysm characterized by potentially life-threatening hypovolemic shock. In these instances in which time does not allow for diagnostic tools, exploratory thoracotomy could incidentally identify a ruptured mediastinal bronchial artery aneurysm as the bleeding site and allow treatment. The use of a partial femorofemoral bypass may be life-saving in patients who are in hemodynamically unstable condition. Moreover, in pa- tients who are in hemodynamically stable condition, femoro-femoral bypass could also be a safe approach, better assuring the surgical exploration of ruptured bronchial artery aneurysm and thereby avoiding problems of uncontrollable bleeding. Mediastinal bronchial artery aneurysm can also be incidentally identified on chest CT scans $^{8,9}$ or exceptionally on conventional chest $\mathrm{x}$-ray films ${ }^{1}$ during investigations of bronchiectasis or bronchopulmonary diseases. In our patient, a contrast chest CT scan performed in a local hospital demonstrated the presence of a suspicious mediastinal mass near the descending aorta, but the variety of vascular structures in the mediastinum that could interfere with interpretation did not permit the diagnosis of ruptured bronchial artery aneurysm to be confirmed with certainty. Although contrast CT scan reveals a high index of suspicion for mediastinal or intrapulmonary bronchial artery aneurysm, ${ }^{10}$ definite diagnosis is confirmed by selective bronchial artery angiography, which additionally enables therapeutic embolization with either balloons or steel coils. ${ }^{4}$ Transcatheter embolization of a bronchial artery may be successful in obliterating the blood flow to the aneurysm and stopping bleeding in hemodynamically stable patients with no evidence of life-threatening bleeding. Embolization succeeded in excluding the aneurysm in three cases of mediastinal bronchial artery aneurysm. ${ }^{4,8,11}$ However, embolization of the aneurysm in which only a short segment exists between the aneurysm and aorta could cause iatrogenic complications and render the procedure inefficient. ${ }^{10}$ In cases of mediastinal bronchial artery aneurysm manifested by hemoptysis, lobectomy seems to be the standard surgical technique, with four of the five 
reported cases being managed in this manner. In one case, lobectomy was performed after bleeding was first controlled by transcatheter embolization. ${ }^{8}$

We have stressed that incidentally detected mediastinal bronchial artery aneurysms of any cause cannot be assumed to be stable, and in the light of the collected case histories wherein spontaneous rupture led to life-threatening bleeding, intervention should be favored, regardless of the presence or absence of symptoms. In addition, because of the variety of clinical pictures of ruptured bronchial artery aneurysms mimicking other vascular entities and the various mediastinal vessels causing confusion, the identification of the vascular nature of a mediastinal mass in hemodynamically stable patients should be mandatory to better guide the type of therapeutic approach.

\section{REFERENCES}

1. Fujita J, Akashi K, Kunikane $\mathrm{H}$, et al. A case of bronchial artery aneurysm demonstrating a mass shadow on chest $\mathrm{x}$-ray film. Nippon Kyobu Shikkan Gakkai Zasshi 1991;29:1591-5.

2. Hall RJC, Miller GAH, Kerr IH. Ruptured bronchial artery aneurysm mimicking aortic dissection. Br Heart J 1977;39: 909-10.

3. Abet D, Pietri J. Rupture d'anévrysme d'une artère bron- chique, sur séquestration pulmonaire, simulant une dissection aortique. J Chir 1981;118:743-6.

4. Ishizaki N, Shimokawa $\mathrm{S}$, Tanaka $\mathrm{K}$, et al. Ruptured bronchial artery aneurysm associated with pleural telangiectasis and tortuous portal obstruction: report of a case. Jpn J Surg 1995;25:852-4.

5. Hirano N, Maeda $H$. Two cases of bronchial artery aneurysm. Nippon Igaku Hoshasen Gakkai Zasshi (J Jpn Radiol Soc) $1976 ; 36: 82$.

6. Chantepie A, Robert M, Pelletier J, et al. Anévrysme mycotique d'une artère bronchique. Chir Pediatr 1980;21: 407-10.

7. Watanabe S, Matayoshi Y, Takeshita H, et al. Two cases of bronchial artery aneurysm. Hirosaki Med J 1981;33:512-3.

8. Osada H, Kawada T, Ashida H, Sodemoto $Y$, Noguchi T. Bronchial artery aneurysm. Ann Thorac Surg 1986;41:440-2.

9. Shaer AH, Bashist B. Computed tomography of bronchial artery aneurysm with erosion into the esophagus. J Comput Assist Tomogr 1989;13:1069-71.

10. Remy-Jardin M, Remy J, Ramon P, Fellous G. Mediastinal bronchial artery aneurysm: dynamic computed tomography appearance. Cardiovasc Intervent Radiol 1991;14:118-210.

11. Cearlock JR, Fontaine AB, Urbaneja A Spigos DG. Endovascular treatment of a posttraumatic bronchial artery pseudoaneurysm. J Vasc Interv Radiol 1995;6:495-6.

\section{CEREBRAL EMBOLIZATION DURING TRANSMYOCARDIAL LASER REVASCULARIZATION}

Hilary P. Grocott, MD, FRCPC, ${ }^{a}$ David W. Amory, MD, PhD, ${ }^{a}$ Edward Lowry, BA, ${ }^{\text {a }}$ Mark F. Newman, MD, James E. Lowe, MD, ${ }^{\mathrm{b}}$ and Fiona M. Clements, MD, ${ }^{\mathrm{a}}$ Durham, N.C.

Transmyocardial laser revascularization (TMLR) is a relatively new procedure used to treat patients with severe inoperable coronary artery disease. ${ }^{1}$ During the course of the procedure, an epicardial carbon dioxide laser is placed on the heart. Discharges from the laser create transmural myocardial channels permitting the flow of oxygenated intraventricular blood into the ischemic myocardium. Laser penetration can be observed at the surface of the heart

From the Departments of Anesthesiology ${ }^{a}$ and Surgery, ${ }^{b}$ Duke Heart Center, Duke University Medical Center, Durham, N.C.

Received for publication March 4, 1997; accepted for publication March 17, 1997.

Address for reprints: Hilary P. Grocott, MD, Department of Anesthesiology, Box 3094, Duke University Medical Center, Durham, NC 27710.

J Thorac Cardiovase Surg 1997;114:856-8

Copyright (1) 1997 by Mosby-Year Book, Inc.

$0022-5223 / 97 \$ 5.00+0 \quad \mathbf{1 2 / 5 4 / 8 1 9 4 4}$
Table I. Results

\begin{tabular}{ccccccc}
\hline & TMLR & Total & Embolil & \multicolumn{2}{c}{ Percent CerSO $\mathrm{S}_{2}$} & \\
Patient & pulses & emboli & pulse & Before & During & After \\
\hline 1 & 27 & 716 & 27 & & & \\
2 & 44 & $*$ & $*$ & & & \\
3 & 29 & 954 & 33 & & & \\
4 & 44 & 1509 & 34 & & & \\
5 & 15 & 159 & 11 & 65 & 65 & 67 \\
6 & 22 & 238 & 11 & 66 & 65 & 68 \\
7 & 18 & 637 & 35 & & & \\
8 & 13 & 96 & 7 & & & \\
9 & 16 & 350 & 22 & & & \\
10 & 22 & 316 & 14 & 66 & 66 & 66 \\
11 & 21 & 394 & 19 & 63 & 63 & 64 \\
Median & 23 & 350 & 22 & 65 & 65 & 66 \\
Range & $13-44$ & $96-1509$ & $7-35$ & & & \\
\hline
\end{tabular}

$T M L R$, Transmyocardial laser revascularization; $\mathrm{CerSO}_{2}$, cerebral regional oxygen saturation measured by near-infrared spectroscopy (NIRS). *TCD tape malfunction (no recorded signal could be reviewed); only patients 5, 6, 10, and 11 had NIRS performed. 